\title{
PERLAKUAN AKUNTANSI TERHADAP MAIN PRODUCT DAN BY PRODUCT SERTA PENGARUHNYA TERHADAP LABA UMKM KOPI BUBUK ISTIMEWA
}

\author{
Susi Susanti ${ }^{1}$, Eri Triharyati ${ }^{2}$ \\ ${ }^{1,2}$ Program Studi Akuntansi, Universitas Bina Insan, Lubuklinggau \\ E-mail : ${ }^{1}$ suci.speed1017@gmail.com, ${ }^{2}$ eri_triharyati@ univbinainsan.ac.id
}

\begin{abstract}
ABSTRACK
This research huses descriptive equalitati veresearch. Special Ground Coffee UKM has not done by product accounting treatment. Where salesor profits from by-product shave not been included in the Profit/Lossreport. For this reason, there searc hersdescribe 4 accounting treatments that include sales or profit sfrom by-product sinto the financial statement sof the Special Ground Coffee UKM. There are 4 treatments thatare analyzed, namely 1) By-product streatedas other profit canincrease the total profit. For 2015 it canincrease profits by 30.44\%, In 2016 it canincrease profits by25.53\%, in 2017 it canincrease profits by3.37\%, in 2018 it canincrease profits by $6.53 \%$ and in 2019 it can increase profits by 0.66\%.2) Accounting treatment forby-product profi tincreases thema in product sales profit,whichcaninc rease the total profitin 2015 by 30.44\%, 2016 by 25.53\%, 2017 by 3.37\% andin 2018 by 6.53\%.3)The accounting treatment of by-product sales reduces the cost of goods soldf or the main products canin crease the total profit in 2015 by 57.81\%,2016 by 61.33\%, 2017 by 24.45\%, 2018 by 29.27\%, year 2019 canin crease profits by $19.31 \%$ from Rp.65,959,700 to Rp.81,742,100.4)The accounting treatmen tof by product profit reduces the total cost of producing the main product can in crease the total profit in 2015 by $30.44 \%$, in 2016 by $25.53 \%$, in 2017 by 3.37\%, in 2018 by $6.53 \%$ from Rp.51,223,500 andin 2019 canin crease profits by $0.66 \%$.
\end{abstract}

Keywords : Accounting Treatment, Main Product, By-product

\section{ABSTRAK}

Penelitian ini menggunakan jenis penelitian deskriptif kualitatif. UKM ( Usaha Kecil Menengah) Kopi Bubuk Istimewa belum melakukan perlakuan akuntansi produk sampingan. Dimana penjualan dan laba atau rugi dari produk sampingan belum dimasukan ke dalam laporan Laba/Rugi, Untuk itu Peneliti mendeskripsikan 4 perlakuan akuntansi terhadap produk sampingan dengan memasukan penjualan dan laba atau rugi dari produk sampingan ke dalam laporan keuangan UKM Kopi Bubuk Istimewa. Adapun 4 perlakukan yang dianalisis yaitu : 1). Produk sampingan diperlakukan sebagai laba lain-lain dapat meningkatkan total laba.Untuk tahun2015 dapat meningkatkan laba sebesar 30,44\%,tahun 2016 dapat meningkatkan laba sebesar 25,53\%,tahun2017 dapat meningkatkan laba sebesar 3,37\%, tahun 2018 dapat meningkatkan laba sebesar 6,53\% dan tahun 2019 dapat meningkatkan laba sebesar 0,66\%. 2). Perlakuan akuntansi untuk laba produk sampingan menambah laba penjualan produk utama dapat meningkatkan total laba tahun 2015 sebesar 30,44\%, tahun2016 sebesar 25,53\%,tahun 2017 sebesar 3,37\% dan tahun 2018 sebesar 6,53\%. 3). Perlakuan akutansi penjualan produk sampingan mengurangi harga pokok penjualan produk utama dapat meningkatkan total laba tahun 2015 sebesar 57,81\%,tahun 2016 sebesar 61,33\%,tahun2017sebesar 24,45\%, tahun 2018 sebesar 29,27\%,tahun 2019 dapat meningkatkan laba sebesar 19,31\% dari Rp.65.959.700 menjadi Rp.81.742.100. 4). Perlakuan akutansi laba produk sampingan mengurangi biaya total produksi produk utama dapat meningkatkan total laba tahun2015sebesar 30,44\%,tahun2016 sebesar 25,53\%, tahun 2017 sebesar 3,37\%, tahun 2018 sebesar 6,53\% dari Rp.51.223.500 dan tahun 2019 dapat meningkatkan laba sebesar $0,66 \%$.

Kata kunci : Perlakuan Akuntansi, Produk Utama, Produk Sampingan 


\section{PENDAHULUAN}

Kopi Bubuk Istimewa Kelurahan Muara Enim, Kecamatan Lubuk Linggau Barat 1 merupakan salah satu UKM yang bergerak dibidang pengilinggan biji kopi yang menghasilkan produknya dari biaya bersama (joint cost) dengan memanfaatkan biji kopi sebagai bahan bakunya. Produk yang dihasilkan adalah Kopi merupakan produk utama dan pupuk sebagai produk sampingan. Perkembangan volume produksi kopi dan pupuk pada tahun 2015-2019 dapat dilihat pada tabel 1 berikut:

\section{Tabel 1}

\section{Hasil Produksi Kopi dan Pupuk UKM}

\section{Kopi Bubuk Istimewa Tahun 2015-2019}

\begin{tabular}{|c|c|c|c|c|c|c|}
\hline \multirow[t]{2}{*}{ Th } & \multicolumn{4}{|c|}{ Volume Produksi dalam (kg) } & \multirow{2}{*}{$\begin{array}{l}\text { Jumlah } \\
\text { Produksi } \\
(\mathrm{Kg})\end{array}$} & \multirow{2}{*}{$\begin{array}{l}\text { Jumlah } \\
\text { Penjualan } \\
\text { (Rp) }\end{array}$} \\
\hline & $\begin{array}{c}\text { Bubuk } \\
\text { Kopi } \\
\text { (Kg) }\end{array}$ & $\begin{array}{l}\text { Penjualan } \\
\text { (Rp) }\end{array}$ & $\begin{array}{c}\text { Pupuk } \\
(\mathrm{Kg})\end{array}$ & $\begin{array}{c}\text { Penjualan } \\
\text { (Rp) }\end{array}$ & & \\
\hline 2015 & 9.642 & 482.100 .000 & 1.446 & 21.694 .500 & 11.088 & 503.794 .500 \\
\hline 2016 & 8.564 & 471.020 .000 & 1.285 & 22.480 .500 & 9.849 & 493.500 .500 \\
\hline 2017 & 8.755 & 503.412 .500 & 1.313 & 22.981 .875 & 10.068 & 526.394 .375 \\
\hline 2018 & 8.565 & 492.487 .500 & 1.285 & 21.198 .375 & 9.850 & 513.685 .875 \\
\hline 2019 & 8.768 & 543.616 .000 & 1.315 & 15.782 .400 & 10.083 & 559.398 .400 \\
\hline
\end{tabular}

Sumber Data : Kopi Bubuk Istimewa

Berdasarkan tabel 1 diatas dapat dideskripsikan Jika diperhatikan dari tahun 2015-2019 jumlah produk sampingan pupuk hampir 1/4 dari produk utama yaitu bubuk kopi. Jumlah produksi yang tertera ditabel.1 adalah jumlah produksi bubuk kopi dengan pupuk sebagai produk sampingan. Produk sampingan ini memiliki biaya produksi setelah titik pemisahan (separable cost), karena diperlukan proses pengeringan setelah terpisah dari produk utama. Biaya produksi tersebut meliputi biaya tenaga kerja langsung dan biaya overhead pabrik saja, dengan tidak menggunakan biaya bahan baku lagi. Sebab,ia tidak diolah lebih lanjut untuk menjadi produk baru. Biaya produksi yang timbul setelah titik pemisahan (split off point) Ini oleh perusahaan dibebankan keatas produk utama. Fakta dilapangan menunjukan, UKM Kopi Bubuk Istimewa ini masih menggunakan metode sederhana dimana hanya menghitung total pengeluaran sebagi unsur biaya tanpa memperhatikan kelompok biaya produksi maupun nonproduksi,unsur biaya produksi seperti biaya bahan baku,biaya tenaga kerja tidak langsung dan biaya overhead pabrik (BOP).

Di UKM Kopi Bubuk Istimewa yang mengolah suatu bahan baku dalam satu proses produksi yang sama untuk menghasilkan beberapa jenis produk, dibutuhkan pengalokasian biaya secara tepat kesetiap produk yang telah dihasilkan. Penentuan HPP (Harga Pokok Produksi) menjadi masalah yang harus diatasi UKM Kopi Bubuk Istimewa untuk memberikan penentuan harga jual yang tepat sehingga dapat menghasilkan laba yang optimal. Harga pokok produksi (HPP) sangat menentukan laba rugi perusahaan.. UKM Kopi Bubuk Istimewa belum menerapkan perlakuan akuntansi khususnya pencatatan transaksi sehari-hari yang berkaitan dengan produk sampingan. Seharusnya perusahaan yang satu bersaing dengan perusahaan yang lain dalam menghasilkan produk yang sejenis maupun produk substitusi.Oleh karena itu, dalam laporan laba / rugi (UKM) Kopi Bubuk Istimewa perlu dihitung dengan teliti dalam memperlakukan profitabilitas penjualan pupuk sebagai profitabilitas produk sampingan sebesar nilai kotornya. Berdasarkan latar belakang masalah tersebut, Peneliti tertarik untuk melakukan penelitian dengan judul "Perlakuan Akuntansi Terhadap Main Product dan By product Serta Pengaruhnya terhadap Laba UMKM Kopi Bubuk Istimewa”.

\section{TINJAUAN PUSTAKA}

\subsection{Pengertian Produk Utama dan Produk Sampingan \\ Pada sebuah perusahaan yang} memproduksi barang mentah menjadi barang jadi akan menghasilkan 2 macam produk yaitu produk utama dan produk sampingan. Produk utama adalah produk yang 
mempunyai nilai jual lebih tinggi dari produk sampingan. Produk utama adalah produk penting dan menjadi tujuan utama dari target pemasaran perusahaan. Proses produksipun disetting sepenuhnya untuk menghasilkan produk andalan ini. Sebagian besar biaya produksi yang telah dikeluarkan digunakan untuk mendukung produksi produk utama ini [3]. Dalam mengolah produk bersama atau coproduct dapat dihasilkan produk utama dan produk sampingan. Produk utama adalah produk yang dihasilkan berdasarkan dari tujuan utama atau pokok operasi perusahaan. Umumnya kuantitas dan nilainya relative lebih besar [4]. Sedangkan Produk sampingan adalah suatu produk dengan total nilai yang relative kecil dan dihasilkan secara simultan atau bersamaan dengan suatu produk lain yang total nilainya lebih besar[3]. Selanjutnya defenisi produk sampingan (By Product) adalah produk yang diproduksi bersama - sama dengan produk lain tetapi mempunyai harga jual yang relative lebih rendah dari produk lainnya[2]. Produk sampingan merupakan satu produk yang mempunyai nilai penjualan rendah dibandingkan dengan nilai penjualan produk utama[2]

\subsection{Prinsip-Prinsip Dasar Produk Utama dan Produk Sampingan}

Produk utama dan produk sampingan mempunyai prinsip dasar dalam penerapannya yaitu sebagai berikut[2]:

1. Produk utama dan produk sampingan akan dijual oleh perusahaan

2. Produk Sampingan (By Product) akan digunakan kembali oleh perusahaan untuk proses produksinya

3. Produk Sampingan (By Product) akan dibuang oleh perusahaan

Prinsip dasar produk utama dan produk sampingan sebagai berikut[4]:

a. Hasil penjualan produk sampingan diperlakukan sebagai profitabilitas lainlain/profitabilitas diluar usaha. b. Hasil penjualan produk sampingan diperlakukan sebagai tambahan terhadap hasil penjualan produk utama. Dengan demikian dalam cara ini, profitabilitas usaha bertambah.

c. Hasil produk sampingan diperlakukan mengurangi harga pokok penjualan.

d. Hasil penjualan produk sampingan diperlakukan mengurangi total biaya produksi.

e. Nilai pasar produk sampingan dikurangkan ketotal biaya produksi (Metode Nilai Pasar/Reversal Cost Method)

\subsection{Metode Perlakuan Akuntansi produk} utama dan produk sampingan

Adapun metode untuk mengalokasikan biaya bersama kepada produk utama dan produk sampingan yaitu sebagai berikut[3] :

1. Metode tanpa harga pokok (noncostmethods)

Metode yang tidak mencoba menghitung harga pokok produk sampingan atau persediaannya,tetapi memperlakukan profitabilitas penjualan produk sampingan sebagai profitabilitas atau pengurang biaya produksi.

2. Metode harga pokok (costmethods) Metode yang mencoba mengalokasikan sebagian biaya bersama kepada produk sampingan dan menentukan harga pokok persediaan produk atas dasar biaya yang dialokasikan tersebut.

3. Metode Profitabilitas Bersih

Dalam metode ini, profitabilitas dari penjualan produk sampingan dikurangi dengan seluruh biaya yang terjadi setelah titik pisah.

Ada beberapa metode untuk mengalokasikan biaya bersama kepada produk utama dan produk sampingan yaitu sebagai berikut [4]:

a. Metode tanpa harga pokok (noncostmethods)

Dalam metode ini terdapat 
beberapa cara perlakuan terhadap hasil penjualan produk sampingan sebagai berikut:

a) Hasil penjualan produk sampingan diperlakukan sebagai Laba lain -lain / Laba diluar usaha.

b) Hasil penjualan produk sampingan diperlakukan sebagai tambahan terhadap hasil penjualan produk utama. Dengan demikian dalam cara ini Laba usaha bertambah.

c) Hasil produk sampingan diperlakukan mengurangi harga pokok penjualan.

d) Hasil penjualan produk sampingan diperlakukan mengurangi total biaya produksi.

b. Metode harga pokok (costmethods) Dalam metode ini harga pokok produk sampingan ditetapkan sebesar harga beli / nilai pengganti (Replacement Cost) yang berlaku di pasar. Harga pokok tersebut dikredit perkiraan"Barang Dalam Proses Bahan Baku".

c. Metode Laba Bersih

Biaya setelah titik pisah meliputi biaya administrasi,biaya pemasaran dan biaya pemrosesan lebih lanjut produk sampingan. Profitabilitas bersih produk sampingan disajikan dalam laporan RugiLaba sebagai:

a) Laba lain-lain

b) Menambah Laba penjualan produk utama

c) Mengurangi harga pokok penjualan produk utama

d) Mengurangi biaya total produksi produk utama

Berdasarkan pendapat diatas, dapat disimpulkan bahwa, metode untuk mengalokasikan biaya bersama kepada produk utama dan produk sampingan adalah metode tanpa harga pokok (non-cost methods), metode harga pokok (cost methods) dan metode profitabilitas bersih.

3 Harga Pokok Produksi

Harga Pokok Produksi adalah kumpulan biaya produksi yang terdiri dari bahan baku langsung,biaya tenaga kerja langsung dan biaya overhead pabrik ditambah persediaan produk dalam proses awal dan dikurang persediaan produk dalam proses akhir.Harga pokok produksi terikat pada periode waktu tertentu. Harga pokok produksi akan sama dengan biaya produksi apabila tidak ada persediaan produk dalam proses awal dan akhir[4].

Prinsip dasar dari harga pokok produksi terdiri dari biaya bahan baku langsung,biaya tenaga kerja langsung,dan biaya overhead pabrik[5].

a. Biaya Bahan Baku Langsung

Bahan baku merupakan bahan yang membentuk bagian menyeluruh produk jadi.

b. Biaya Tenaga Kerja Langsung

Biaya tenaga kerja merupakan salah satu biaya konversi, disamping biaya overhead pabrik,yang merupakan salah satu biaya untuk mengubah bahan baku menjadi produk jadi.

c. Biaya Overhead Pabrik

Overhead pabrik merupakan bahan tidak langsung dan tenaga kerja tidak langsung serta biaya tidak langsung lainnya yang tidak dapat ditelusuri secara langsung keproduk selesai atau tujuan akhir biaya.

\subsection{Hasil Penelitian Relevan}

1. Nama Peneliti : Evan Bawling dan Victorina Z. Tirayoh (2014) Judul Analisis perhitungan harga pokok dan perlakuan akuntansi atas Produk Sampingan (by product) Pada UD. Sinar Sakti Metode deskriptif kualitatif Hasil penelitian menunjukan metode akuntansi yang digunakan untuk memperlakukan Produk Sampingan (by product) ialah metode harga pokok. [1]

2. Nama Peneliti : Rosario Betris Waroh, Herman Karamoy dan Treesje Runtu (2017) Judul : Perlakuan akuntansi atas Produk Sampingan (by product) pada PT.Royal Coconut Airmadidi Metode deskriptif kualitatif Hasil penelitian ini 
yaitu Perlakuan akuntansi atas Produk Sampingan (by product) yaitu sebagai profitabilitas diluar usaha (Other Income) bukan sebagai pengurang biaya bahan baku pada kegiatan produksi. Sehingga diharapkan perusahaan melakukan pencatatan jurnal atas pengakuan persediaan atas Produk Sampingan (by product) perusahaan, melakukan pencatatan jurnal untuk mengakui penjualan atas Produk Sampingan (by product) sebagai profitabilitas diluar usaha (Other Income), serta menyajikan profitabilitas atas Produk Sampingan (by product) tersebut ke dalam laporan laba rugi perusahaan.[10]

3. Nama Peneliti : Dwi Anisa Pranata, Judul Perlakuan Akuntansi Terhadap Main Product dan By Product Serta Pengaruhnya Terhadap Laba Perusahaan (Studi Kasus Pada Pabrik Tahu dan Tempe Padang Tarok), Metode deskriptif kualitatif Pada Pabrik Tahu dan Tempe Padang Tarok menggunakan metode hasil penjualan produk sampingan diperlakukan sebagai pengurang harga pokok produksi. Sedangkan untuk melakukan perhitungan produk utama dan produk sampingan menggunakan metode nilai pasar. [14]

\section{METODOLOGI PENELITIAN}

\subsection{Tempat Penelitian}

Penelitian ini dilakukan di UKM Kopi Bubuk Istimewa dengan alamat Jl.Patimura RT.002. Kel. Muara Enim, Kecamatan Lubuklinggau Barat I .

\subsection{Sumber Data}

Sumber data yang digunakan dalam penelitian ini adalah data primer dan data sekunder[9], diantaranya adalah sebagai berikut:

1. Data Primer

DataPrimer adalah data yang diperoleh langsung dari narasumber yang ada di perusahaan atau tempat penelitian.
Dalam penelitian ini yakni saat wawancara dengan karyawan atau pegawai perusahaan tentang pengambilan data dari perusahaan.

2. Data Sekunder

Data sekunder merupakan data yang diperoleh dari literature- literature serta tulisan-tulisan yang berhubungan dengan penelitian ini termasuk yang dikumpulkan oleh lembaga pengumpul data dan dipublikasikan kepada pengguna data yang lain.

Berdasarkan urain diatas data yang digunakan dalam penelitian ini adalah data primer dan data sekunder

\subsection{Teknik Pengumpulan Data}

Teknik pengumpulan data sebagai berikut[12]:

1. Observasi

Observasi adalah metode pengumpulan data yang kompleks karena melibatkan berbagai factor dalam pelaksanaan nya. Metode pengumpulan data observasi tidak hanya mengukur sikap dari responden,namun juga dapat digunakan untuk merekam berbagai fenomena yang terjadi.

2. Wawancara

Wawancara adalah tanya jawab antara dua pihak yaitu pewawancara dan nara sumber untuk memperoleh data,keterangan atau pendapat tentang suatu hal.

3. Dokumentasi

Dokumen adalah jenis pengumpulan data yang meneliti berbagai macam dokumen yang berguna untuk bahan analisis.

Adapun teknik pengumpulan data yang digunakan dalam penelitian ini adalah Wawancara,Observasi, dan Dokumentasi.

\subsection{Prosedur Analisis Data}

Prosedur analisis data yang dilakukan adalah sebagai berikut:

1. Mengamati dan mengumpulkan data tentang metode perlakuan akuntansi 
Vol. 6, No. 2 Desember 2020

p-ISSN : 2502-2911, e-ISSN : 2656-887X

produk sampingan, penentuan harga pokok produksi, dan profitabilitas produk Kopi Bubuk Istimewa di Kelurahan Muara Enim Kecamatan Lubuklinggau Barat Kota Lubuklinggau

2. Membandingkan data yang diperoleh dengan teori yang diungkapkan dalam landasan teori berupa pendapat-pendapat para ahli (Mulyadi dan Irham Fahmi tentang Produk Utama dan Produk Sampingan)

3. Menganalisis hasil wawancara dan observasi

4. Simpulan

\section{HASIL DAN PEMBAHASAN}

\subsection{Hasil Penelitian}

\section{Produk Utama UMKM Kopi Bubuk Istimewa}

Produk Utama UMKM Kopi Bubuk Istimewa adalah bubuk kopi. Berdasarkan observasi diketahui bahwa UMKM Kopi Bubuk Istimewa memproduksi bubuk kopi pada tahun 2015 sebanyak $9.642 \mathrm{~kg}$,tahun 2016 sebanyak $8.564 \mathrm{~kg}$, tahun 2017adalah sebanyak $8.755 \mathrm{~kg}$, tahun 2018 sebanyak $8.565 \mathrm{~kg}$ dan tahun 2019 sebanyak 8.768 kg.Untuk setiap harga per $\mathrm{kg}$ pertahun berbeda,pada tahun 2015 harga per kg untuk bubuk kopi sebesar Rp.50.000,-.Pada tahun2016 harga per kg untuk bubuk kopi sebesar Rp.55.000,-.Pada tahun 2017 harga per kg untuk bubuk kopi sebesar Rp.57.500,.Pada tahun 2018 harga per kg untuk bubuk kopi sebesar Rp.57.500,-.Pada tahun2019 harga per $\mathrm{kg}$ untuk bubuk kopi sebesar Rp.62.000,-. Untuk lebih jelasnya hasil produksi Produk Utama UMKM Kopi Bubuk Istimewa Tahun 2015-2019 dapat dilihat pada table 2 berikut ini :

\section{Tabel 2}

Hasil Produksi Produk Utama UMKM Kopi Bubuk Istimewa Tahun 2015-2019

\begin{tabular}{|l|l|l|l|l|}
\hline Tahun & Produk & $\begin{array}{c}\text { Jumlah } \\
\text { Produk } \\
\text { si }(\mathrm{Kg})\end{array}$ & $\begin{array}{c}\text { HargaJual } \\
\text { per/kg } \\
(\mathrm{Rp})\end{array}$ & $\begin{array}{c}\text { Jumlah } \\
\text { Penjualan } \\
(\mathrm{Rp})\end{array}$ \\
\hline 2015 & BubukKopi & 9.642 & 50.000 & 482.100 .000 \\
\hline 2016 & BubukKopi & 8.564 & 55.000 & 471.020 .000 \\
\hline
\end{tabular}

\begin{tabular}{|l|l|l|l|l|}
\hline 2017 & BubukKopi & 8.755 & 57.500 & 503.412 .500 \\
\hline 2018 & BubukKopi & 8.565 & 57.500 & 492.487 .500 \\
\hline 2019 & BubukKopi & 8.768 & 62.000 & 543.616 .000 \\
\hline
\end{tabular}

Sumber : UMKM Kopi Bubuk Istimewa, Tahun 2020

\section{Produk Sampingan UMKM Kopi Bubuk Istimewa}

Berikut adalah table hasil produksi produk sampingan UMKM Kopi Bubuk Istimewah.

Tabel 3

Hasil Produksi Sampingan UMKM Kopi Bubuk Istimewa Tahun 2015-2019

\begin{tabular}{|l|l|l|l|l|}
\hline Tahun & Produk & $\begin{array}{c}\text { Jumlah } \\
\text { Produksi } \\
(\mathrm{Kg})\end{array}$ & $\begin{array}{c}\text { HargaJual } \\
\text { per/kg } \\
(\mathrm{Rp})\end{array}$ & $\begin{array}{c}\text { Jumlah } \\
\text { Penjualan } \\
(\mathrm{Rp})\end{array}$ \\
\hline 2015 & Pupuk & 1.446 & 15.000 & 21.694 .500 \\
\hline 2016 & Pupuk & 1.285 & 17.500 & 22.480 .500 \\
\hline 2017 & Pupuk & 1.313 & 17.500 & 22.981 .875 \\
\hline 2018 & Pupuk & 1.285 & 16.500 & 21.198 .375 \\
\hline 2019 & Pupuk & 1.315 & 12.000 & 15.782 .400 \\
\hline
\end{tabular}

Sumber : UMKM Kopi Bubuk Istimewa, Tahun 2020

Berdasarkan tabel.3 untuk hasil produksi kopi UMKM Kopi Bubuk Istimewa untuk produk sampingan diperoleh pendapatan yang berasal dari penjualan pada tahun 2015 sebesar Rp.21.694.500,-. Pada tahun 2016 diperoleh pendapatan sebesar Rp.22.480.500,-.Pada tahun 2017 diperoleh pendapatan sebesar Rp. 22.480.500,-.Pada tahun 2018 diperoleh pendapatan sebesar Rp. 21.198.375,-.Pada tahun 2019 diperoleh pendapatan sebesar Rp. 15.782.400,-.

\section{Penentuan Harga Pokok di UMKM Kopi Bubuk Istimewa}

Penentuan Harga Pokok di UMKM Kopi Bubuk Istimewa dengan menggunakan metode Full costing. Full costing merupakan metode penentuan harga pokok produksi yang memperhitungkan semua unsur biaya produksi kedalam harga pokok produksi yang terdiri dari biaya bahan baku, biaya tenaga kerja langsung, dan biaya overhead pabrik baik yang berperilaku variable maupun tetap.

a. Biaya Bahan Baku

Untuk perhitungan biaya bahan baku 
pada tahun 2015-2019 dapat dilihat secara rinci di tabel berikut :

\section{Tabel 4}

Total Biaya Bahan Baku Aktual UMKM Kopi Bubuk Istimewa Tahun 2015-2019

\begin{tabular}{|c|l|l|l|l|l|}
\hline Tahun & $\begin{array}{l}\text { Bahan } \\
\text { Baku }\end{array}$ & $\begin{array}{l}\text { Biji } \\
\text { Kopi } \\
(\mathrm{Kg})\end{array}$ & $\begin{array}{l}\text { Hasil } \\
\text { Produksi } \\
\text { Bubuk } \\
\text { Kopi } \\
(\mathrm{kg})\end{array}$ & $\begin{array}{l}\text { Biaya } \\
\text { Bahan } \\
\text { Baku } \\
(\mathrm{Rp})\end{array}$ & $\begin{array}{l}\text { Jumlah } \\
\text { Biaya } \\
\text { Bahan } \\
\text { Baku (Rp) }\end{array}$ \\
\hline 2015 & $\begin{array}{l}\text { Biji } \\
\text { Kopi }\end{array}$ & 38.568 & 9.642 & 25.000 & 241.050 .000 \\
\hline 2016 & $\begin{array}{l}\text { Biji } \\
\text { Kopi }\end{array}$ & 34.256 & 8.564 & 27.500 & 235.510 .000 \\
\hline 2017 & $\begin{array}{l}\text { Biji } \\
\text { Kopi }\end{array}$ & 35.020 & 8.755 & 23.500 & 205.742 .500 \\
\hline 2018 & $\begin{array}{l}\text { Biji } \\
\text { Kopi }\end{array}$ & 34.260 & 8.565 & 24.000 & 205.560 .000 \\
\hline Kiji & 35.072 & 8.768 & 27.500 & 241.120 .000 \\
\hline
\end{tabular}

Sumber : UMKM Kopi Bubuk Istimewa, Tahun 2020

\section{b. Biaya Tenaga Kerja Langsung}

Untuk biaya tenaga kerja langsung,UMKM ini memperkerjakan 4 orang karyawan dibidang produksi yang berhubungan langsung pada saat produksi berlangsung dan 3 orang dibagian pengemasan.Waktu kerja dimulai pukul 07.00 WIB sampai dengan pukul 14.00 WIB. Waktu kerja selama 6 hari sepekan dengan sehari libur 1hari dengan upahlorangRp 75.000,00 per hari untuk bagian produksi. Sedagkan untuk bagian pengemasan sebesar Rp.50.000,00 per hari.Untuk rincian perhitungan dapat dilihat ditabel berikut:

\section{Tabel 5}

Total Biaya Tenaga Kerja Langsung untuk Bagian Produksi UMKM Kopi

Bubuk Istimewa Tahun 2015-2019

\begin{tabular}{|l|l|l|l|l|}
\hline Tahun & $\begin{array}{l}\text { Jumlah } \\
\text { Pekerja } \\
\text { (Orang) }\end{array}$ & $\begin{array}{l}\text { Tarif } \\
\text { Upah } \\
\text { perHari }\end{array}$ & $\begin{array}{l}\text { Jumlah } \\
\text { Hari } \\
\text { (Tahun) } \\
\text { (Rp) }\end{array}$ & $\begin{array}{l}\text { TotalBiaya } \\
\text { TenagaKerja } \\
\text { (Tahun) }(\mathrm{Rp})\end{array}$ \\
\hline 2015 & 4 & 75.000 & 288 & 86.400 .000 \\
\hline 2016 & 4 & 75.000 & 288 & 86.400 .000 \\
\hline 2017 & 4 & 75.250 & 288 & 86.688 .000 \\
\hline 2018 & 4 & 80.000 & 288 & 92.160 .000 \\
\hline 2019 & 4 & 80.000 & 288 & 92.160 .000 \\
\hline
\end{tabular}

Sumber : UMKM Kopi Bubuk Istimewa, Tahun 2020
Tabel 6

Total BiayaTenaga Kerja Langsung untuk Bagian Pengemasan UMKM Kopi Bubuk Istimewa Tahun 2015-2019

\begin{tabular}{|l|l|l|l|l|}
\hline Tahun & $\begin{array}{l}\text { Jumlah } \\
\text { Pekerja } \\
\text { (Orang) }\end{array}$ & $\begin{array}{l}\text { Tarif } \\
\text { Upah } \\
\text { perHari }\end{array}$ & $\begin{array}{l}\text { umlah } \\
\text { Hari } \\
\text { (Tahun) } \\
\text { (Rp) }\end{array}$ & $\begin{array}{l}\text { TotalBiaya } \\
\text { Tenaga } \\
\text { Kerja } \\
\text { (Tahun) } \\
\text { (Rp) }\end{array}$ \\
\hline 2015 & 3 & 45.000 & 288 & 38.880 .000 \\
\hline 2016 & 3 & 45.000 & 288 & 41.040 .000 \\
\hline 2017 & 3 & 47.500 & 288 & 43.200 .000 \\
\hline 2018 & 3 & 50.000 & 288 & 43.200 .000 \\
\hline 2019 & 3 & 50.000 & 288 & 43.200 .000 \\
\hline
\end{tabular}

Sumber : UMKM Kopi Bubuk Istimewa, Tahun 2020

\section{Tabel 7}

Total Biaya Tenaga Kerja Langsung UMKM Kopi Bubuk Istimewa

Tahun 2015-2019

\begin{tabular}{|c|c|c|c|}
\hline Tahun & \multicolumn{2}{|c|}{ Total BiayaTenagaKerja(Tahun) } & \multirow{2}{*}{$\begin{array}{c}\text { Total } \\
\text { BiayaTenagaKerja } \\
\text { (Tahun) }\end{array}$} \\
\hline & $\begin{array}{l}\text { Bagian Produksi } \\
\text { (Rp) }\end{array}$ & $\begin{array}{c}\text { Bagian } \\
\text { Pengemasan } \\
\text { (Rp) }\end{array}$ & \\
\hline 2015 & 86.400 .000 & 38.880 .000 & 125.280 .000 \\
\hline 2016 & 86.400 .000 & 38.880 .000 & 125.280 .000 \\
\hline 2017 & 86.688 .000 & 41.040 .000 & 127.728 .000 \\
\hline 2018 & 92.160 .000 & 43.200 .000 & 135.360 .000 \\
\hline 2019 & 92.160 .000 & 43.200 .000 & 135.360 .000 \\
\hline
\end{tabular}

Sumber : UMKM Kopi Bubuk Istimewa, Tahun 2020

Tabel 8

\section{Biaya Overhead Pabrik UMKM Kopi}

Bubuk Istimewa Tahun 2015-2019

\begin{tabular}{|c|c|c|c|c|c|}
\hline \multirow[t]{2}{*}{ Komponen BOP } & \multicolumn{5}{|c|}{ Biaya Overhead Pabrik (Rp) } \\
\hline & 2015 & 2016 & 2017 & 2018 & 2019 \\
\hline B.Pengemasan & 19.284 .000 & 17.128 .000 & 19.698 .750 & 21.412 .500 & 21.920 .000 \\
\hline B.Kayu Bakar & 7.231 .500 & 6.423 .000 & 6.566 .250 & 6.423 .750 & 6.576 .000 \\
\hline B.Marketing & 8.195 .700 & $\begin{array}{l}7.279 .400 \\
\end{array}$ & 7.441 .7507 & 7.280 .250 & 7.452 .800 \\
\hline B.Listrik & 42.000 .000 & 42.000 .000 & 42.000 .000 & 42.000 .000 & 42.000 .000 \\
\hline B.Transportasi & 18.177 .500 & 18.177 .500 & 18.177 .500 & 18.177 .500 & 18.177 .500 \\
\hline B.Pml. Pabrik & 1.500 .000 & 1.500 .000 & 1.500 .000 & 1.500 .000 & 1.500 .000 \\
\hline B.Penyusutan & 1.000 .000 & 1.000 .000 & 1.000 .000 & 1.000 .000 & 1.000 .000 \\
\hline B.Asuransi & 1.000 .000 & 1.000 .000 & 1.000 .000 & 1.000 .000 & 1.000 .000 \\
\hline $\begin{array}{r}\text { B.Khusus } \\
\text { BOP }\end{array}$ & 1.550 .000 & 1.550 .000 & 1.550 .000 & 1.550 .000 & 1.550 .000 \\
\hline Jumlah & 99.938 .700 & 96.057 .900 & 98.934 .250 & $\begin{array}{l}100.344 .00 \\
0\end{array}$ & 101.176 .300 \\
\hline
\end{tabular}

Sumber : Data Olahan,Tahun 2020

c. Laba UMKM Kopi Bubuk Istimewa

1) Laba Produk Utama UMKM Kopi Bubuk Istimewa Laba produk utama UMKM Kopi Bubuk Istimewa pada tahun 2015 sebagai berikut: 


\section{Tabel 9}

Laba Produk Utama UMKKM Kopi Bubuk Istimewa Tahun 2015

\begin{tabular}{|l|l|l|}
\hline Uraian & Jumlah & Jumlah \\
\hline Penjualan & & 482.100 .000 \\
\hline B.Bahan Baku & 241.050 .000 & \\
\hline B.TKL & 125.280 .000 & \\
\hline BOP & 99.938 .700 & \\
\hline $\begin{array}{l}\text { Jlh.Harga } \\
\text { Pokok } \\
\text { Produksi }\end{array}$ & & 466.268 .700 \\
\hline Laba & & \\
\hline
\end{tabular}

Sumber : Data Olahan,Tahun 2020

Tabel 10

Laba Produk Utama UMKM Kopi Bubuk Istimewa Tahun 2016

\begin{tabular}{|l|r|l|}
\hline Uraian & Jumlah & Jumlah \\
\hline Penjualan & & 471.020 .000 \\
\hline B.Bahan Baku & 235.510 .000 & \\
\hline B.TKL & 125.280 .000 & \\
\hline BOP & 96.057 .900 & \\
\hline $\begin{array}{l}\text { Jlh.Harga Pokok } \\
\text { Produksi }\end{array}$ & 456.847 .900 \\
\hline Laba & & 14.172 .100 \\
\hline \multicolumn{2}{|l|}{ Sumber : Data Olahan,Tahun 2020 } \\
\hline
\end{tabular}

Tabel 11

Laba Produk Utama UMKM Kopi Bubuk Istimewa Tahun 2017

\begin{tabular}{|l|c|l|}
\hline Uraian & Jumlah & Jumlah \\
\hline Penjualan & & 503.412 .500 \\
\hline B.Bahan Baku & 205.742 .500 & \\
\hline B.TKL & 127.728 .000 & \\
\hline BOP & 98.934 .250 & \\
\hline $\begin{array}{l}\text { Jlh.Harga Pokok } \\
\text { Produksi }\end{array}$ & & 432.404 .750 \\
\hline Laba & & 71.007 .750 \\
\hline
\end{tabular}

Sumber : Data Olahan,Tahun 2020

Tabel 12

Laba Produk Utama UMKM Kopi Bubuk Istimewa Tahun 2018

\begin{tabular}{|l|l|l|}
\hline Uraian & Jumlah & Jumlah \\
\hline Penjualan & & 492.487 .500 \\
\hline B.Bahan Baku & 205.560 .000 & \\
\hline B.TKL & 135.360 .000 & \\
\hline BOP & 100.344 .000 & \\
\hline $\begin{array}{l}\text { Jlh.Harga Pokok } \\
\text { Produksi }\end{array}$ & & 441.264 .000 \\
\hline Laba & & 51.223 .500 \\
\hline
\end{tabular}

Sumber : Data Olahan,Tahun 2020

\section{Tabel 13}

Laba Produk Utama UMKM Kopi Bubuk Istimewa Tahun 2019

\begin{tabular}{|c|c|c|}
\hline Uraian & Jumlah & Jumlah \\
\hline Penjualan & & 543.616 .000 \\
\hline B.Bahan Baku & 241.120 .000 & \\
\hline B.TKL & 135.360 .000 & \\
\hline BOP & 101.176 .300 & \\
\hline $\begin{array}{l}\text { Jlh.Harga Pokok } \\
\text { Produksi }\end{array}$ & & 477.656 .300 \\
\hline Laba & & 65.959 .700 \\
\hline
\end{tabular}

2) Laba Produk Sampingan UMKM Kopi Bubuk Istimewa

Berikut Laba Produksi produk sampingan berupa pupuk di UMKM Kopi Bubuk Istimewa pada tahun 2015 :

Tabel 14

Laba Produk Sampingan UMKM Kopi Bubuk Istimewa Tahun 2015

\begin{tabular}{|l|l|l|}
\hline Uraian & Jumlah & Jumlah \\
\hline Penjualan & & 21.694 .500 \\
\hline B.TKL & 14.400 .000 & \\
\hline BOP & 366.945 & \\
\hline $\begin{array}{l}\text { Jlh.Harga Pokok } \\
\text { Produksi }\end{array}$ & & 14.766 .945 \\
\hline Laba & & 6.927 .555 \\
\hline
\end{tabular}

Sumber : Data Olahan,Tahun 2020

Tabel 15

Laba Produk Sampingan UMKM Kopi Bubuk Istimewa Tahun 2016

\begin{tabular}{|l|r|l|}
\hline Uraian & Jumlah & Jumlah \\
\hline Penjualan & & 22.480 .500 \\
\hline B.TKL & 17.280 .000 & \\
\hline BOP & 342.690 & \\
\hline $\begin{array}{l}\text { Jlh.Harga Pokok } \\
\text { Produksi }\end{array}$ & & 17.622 .690 \\
\hline Laba & & 4.857 .810 \\
\hline \multicolumn{2}{|l|}{ Sumber : Data Olahan,Tahun 2020 }
\end{tabular}


Vol. 6, No. 2 Desember 2020

p-ISSN : 2502-2911, e-ISSN : 2656-887X

Tabel 16

Laba Produk Sampingan UMKM Kopi

Bubuk Istimewa Tahun 2017

\begin{tabular}{|l|c|l|}
\hline Uraian & Jumlah & Jumlah \\
\hline Penjualan & & 22.981 .875 \\
\hline B.TKL & 20.160 .000 & \\
\hline BOP & 346.987 & \\
\hline $\begin{array}{l}\text { Jlh.Harga Pokok } \\
\text { Produksi }\end{array}$ & & 20.506 .987 \\
\hline Laba & & 2.474 .888 \\
\hline
\end{tabular}

Sumber : Data Olahan,Tahun 2020

Tabel 17

Laba Produk Sampingan UMKM Kopi

Bubuk Istimewa Tahun 2018

\begin{tabular}{|l|r|l|}
\hline Uraian & Jumlah & Jumlah \\
\hline Penjualan & & 21.198 .375 \\
\hline B.TKL & 17.280 .000 & \\
\hline BOP & 342.712 & \\
\hline $\begin{array}{l}\text { Jlh.Harga Pokok } \\
\text { Produksi }\end{array}$ & & 17.622 .712 \\
\hline Laba & & 3.575 .663 \\
\hline
\end{tabular}

Sumber : Data Olahan,Tahun 2020

Tabel 18

Laba Produk Sampingan UMKM Kopi

Bubuk Istimewa Tahun 2019

\begin{tabular}{|l|r|l|}
\hline Uraian & \multicolumn{1}{|l|}{ Jumlah } & Jumlah \\
\hline Penjualan & & 15.782 .400 \\
\hline B.TKL & 14.400 .000 & \\
\hline BOP & 947.280 & \\
\hline $\begin{array}{l}\text { Jlh.Harga Pokok } \\
\text { Produksi }\end{array}$ & & 15.347 .280 \\
\hline Laba & & 435.120 \\
\hline \multicolumn{2}{|l|}{ Sumber : Data Olahan, Tahun 2020 }
\end{tabular}

\subsection{Pembahasan}

1. Penentuan Harga Pokok Produksi Produk Sampingan

Perhitungan harga pokok produksi adalah untuk mengetahui besarnya biaya produksiyang dikeluarkan untuk memproduksi suatu barang. Menurut Mulyadi (2018:295), pada umumnya indicator harga pokok produksi meliputi biaya produksi itu sendiri yaitu biaya bahan baku, biaya tenaga kerja langsung, dan overhead pabrik.

a) Biaya Bahan Baku

b) BiayaTenagaKerja

c) Biaya Overhead Pabrik

Berikut table perhitungan harga pokok produksi pada UMKM Kopi Bubuk Istimewa

Tabel 19

Harga PokokProduksi

UMKM Kopi Bubuk Istimewa

\begin{tabular}{|l|l|l|l|l|l}
\hline & & 2016 & 2017 & 2018 & 2019 \\
\hline 50.000 & 10.000 & 42.500 & 60.000 & 241.120 .000 \\
\hline 80.000 & 80.000 & 28.000 & 60.000 & 135.360 .000 \\
\hline 8.700 & 7.900 & 4.250 & 44.000 & 101.176 .300 \\
\hline
\end{tabular}

Sumber : Data Olahan,Tahun 2020

2. Laba Produk Sampingan UMKM Kopi

Bubuk Istimewa

Berikut Laba Produksi produk sampingan

UMKM Kopi Bubuk Istimewa pada tahun 2015-2019 sebagai berikut

Tabel 20

Laba Produk Sampingan UMKM Kopi

Bubuk Istimewa Tahun 2015-2019

\begin{tabular}{|l|c|c|l|l|l|}
\hline \multirow{3}{*}{ Uraian } & \multicolumn{5}{|c|}{ Laba Produk Sampingan } \\
\cline { 2 - 6 } & 2015 & 2016 & 2017 & 2018 & 2019 \\
\hline PJ & 21.694 .500 & 22.480 .500 & 22.981 .875 & 21.198 .375 & 15.782 .400 \\
\hline TKL & $(14.400 .000)$ & $(17.280 .000)$ & $20.160 .00)$ & $(17.280 .000)$ & $(14.400 .000)$ \\
\hline BOP & & $(342.690)$ & & $(342.712)$ & \\
& $(366.945)$ & & $(346.987)$ & & $(947.280)$ \\
\hline Laba & 6.927 .555 & 4.857 .810 & 2.474 .888 & 3.575 .663 & 435.120 \\
\hline
\end{tabular}

Sumber : Data Olahan,Tahun 2020

Keterangan

$\mathrm{PJ}=$ Penjualan

TKL $=$ Tenaga Kerja Langsung

BOP = Biaya Overhead Pabrik

JML $=$ Jumlah harga pokok produksi

3. Perlakuan Akutansi Produk Sampingan

Dalam proses produksi.

UMKM Kopi Bubuk Istimewa mengeluarkan biaya produksi seperti bahan baku, biaya tenaga kerja langsung dan biaya overhead pabrik. Biaya-biaya tersebut digunakan untuk menghasilkan produk utama (main product). Dalam memproduksi main product terdapat sisa limbah atau sampah yang dihasilkan dari main product. Sisa limbah atau sampah tersebut disebut dengan produk sampingan (by product). Main product adalah satu produk atau lebih yang nilai jualnya relatif lebih tinggi, yang diproduksi bersama dengan produk lain yang nilai jualnya relative rendah. Main product di 
UMKM Kopi Bubuk Istimewa adalah bubuk kopi setelah diproduksi. Sedangkan by product adalah satu produk atau lebih yang nilai jualnya relative lebih rendah,yang diproduksi bersama dengan produk lain yang nilai jualnya relative lebih tinggi. By productdi UMKM Kopi Bubuk Istimewa adalah ampas bubuk kopi setelah diproduksi yang dijadikan pupuk organic untuk perkebunan hidroponik.

1) Perlakuan Akutansi Produk Sampingan diperlakukan sebagai Laba Lain-Lain Penerapan perlakuan akuntansi dalam laporan laba rugi dimana produk sampingan menjadi laba lain-lain untuk tahun 2015 adalah sebagai berikut:

UMKM Kopi Bubuk Istimewa Laporan Laba Rugi Tahun 2015

Penjualan Produk Bubuk Kopi 482.100.000

Harga Pokok Penjualan :

Biaya Bahan Baku Biji Kopi 241.050.000

Biaya Tenaga Langsung :

Bagian Produksi

86.400 .000

BagianPengemasan

38.880 .000

Biaya Overhead Pabrik

Biaya Pengemasan

19.284 .000

Biaya Kayu Bakar

7.231 .500

Biaya Marketing

8.195 .700

Biaya Listrik

42.000 .000

Biaya Transportasi

18.177 .500

BiayaPemeliharaanPabrik

1.500 .000

Biaya Penyusutan

1.000 .000

Biaya Asuransi

1.000 .000

Biaya Khusus overhead pabrik 1.550.000+ HPP

(466.268.700)-

Laba produk utama 15.831 .300

Laba lain-lain (Produk Sampingan) $\underline{6.927 .555+}$ Total Laba 22.758 .855
Tabel 21

Rekapitulasi Total Laba untuk Perlakuan

Akutansi Produk Sampingan

Diperlakukan Sebagai Laba lain-lain

\begin{tabular}{|l|l|l|l|l|l|}
\hline \multirow{2}{*}{ Uraian } & Laba (Rp) & \multicolumn{5}{|l|}{} \\
\cline { 2 - 6 } & 2015 & 2016 & 2017 & 2018 & 2019 \\
\hline $\begin{array}{l}\text { Laba } \\
\text { (Produk } \\
\text { Utama) }\end{array}$ & 15.831 .300 & 14.172 .100 & 71.007 .750 & 51.223 .500 & 65.959 .700 \\
\hline $\begin{array}{l}\text { Laba } \\
\text { (Produk } \\
\text { Sampingan) }\end{array}$ & 6.927 .555 & 4.857 .810 & 2.474 .887 & 3.575 .662 & 435.120 \\
\hline Total Laba & 22.758 .855 & 19.029 .910 & 73.482 .637 & 54.799 .162 & 66.394 .820 \\
\hline Persentase & $30,44 \%$ & $25,53 \%$ & $3,37 \%$ & $6,53 \%$ & $0,66 \%$ \\
\hline
\end{tabular}

Sumber : Data Olahan,Tahun 2020

Berdasarkan table diatas,dapat dideskripsikan bahwa jika produk sampingan diperlakukan sebagai laba lain-lain dapat meningkatkan total laba.Untuk tahun2015 dapat meningkatkan laba sebesar 30,44\% dari Rp. 15.831.300 menjadi Rp.22.758.855, tahun 2016 dapat meningkatkan laba sebesar 25,53\% dari Rp.14.172.100 menjadi Rp.19.029.910, tahun 2017 dapat meningkatkan laba sebesar $3,37 \%$ dari Rp.71.007.750 menjadi Rp. 73.482.637, tahun 2018 dapat meningkatkan laba sebesar 6,53\% dari Rp. 51.223.500 menjadi Rp.54.799.162,tahun 2019 dapat meningkatkan laba sebesar $0,66 \%$ dari Rp.65.959.700 menjadi Rp.66.394.820.

2) Perlakuan Akutansi Laba Produk Sampingan Menambah Laba Penjualan Produk Utama

Tabel 22

Rekapitulasi Total Laba untuk perlakuan akuntansi untuk laba produk sampingan menambah laba penjualan produk utama

\begin{tabular}{|l|l|l|l|l|l|}
\hline \multirow{2}{*}{ Uraian } & Laba (Rp) & \multicolumn{5}{|l|}{} \\
\cline { 2 - 6 } & 2015 & 2016 & 2017 & 2018 & 2019 \\
\hline $\begin{array}{l}\text { Laba } \\
\text { (Produk }\end{array}$ & 15.831 .300 & 14.172 .100 & 71.007 .750 & 51.223 .500 & 65.959 .700 \\
Utama) & & & & & \\
\hline $\begin{array}{l}\text { Laba } \\
\text { (Produk } \\
\text { Sampingan) }\end{array}$ & 6.927 .555 & 4.857 .810 & 2.474 .887 & 3.575 .662 & 435.120 \\
\hline Total Laba & 22.758 .855 & 19.029 .910 & 73.482 .637 & 54.799 .162 & 66.394 .820 \\
\hline Persentase & $30,44 \%$ & $25,53 \%$ & $3,37 \%$ & $6,53 \%$ & $0,66 \%$ \\
\hline
\end{tabular}


Berdasarkan table diatas, dapat dideskripsikan bahwa perlakuan akuntansi untuk laba produk sampingan menambah laba penjualan produk utama dapat meningkatkan total laba. Untuk tahun 2015 dapat meningkatkan laba sebesar 30,44\% dari Rp.15.831.300 menjadi Rp. 22.758.855, tahun 2016 dapat meningkatkan laba sebesar $25,53 \%$ dari Rp. 14.172.100 menjadi Rp.19.029.910,tahun 2017 dapat meningkatkan laba sebesar $3,37 \%$ dari Rp.71.007.750 menjadi Rp.73.482.637, tahun 2018 dapat meningkatkan laba sebesar 6,53\% dari Rp.51.223.500 menjadi Rp. 54.799.162, tahun 2019 dapat meningkatkan laba sebesar 0,66\% dari Rp. 65.959 .700 menjadi Rp.66.394.820.

1) Perlakuan Akutansi Penjualan Produk Sampingan Mengurangi Harga Pokok Penjualan Produk Utama

Tabel 23

Rekapitulasi Total Laba untuk perlakuan akutansi laba produk sampingan mengurangi biaya total produksi produk utama

\begin{tabular}{|l|l|l|l|l|l|}
\hline Uraian & \multicolumn{5}{|l}{ Laba ( Rp ) } \\
\cline { 2 - 6 } & 2015 & 2016 & 2017 & 2018 & 2019 \\
\hline Laba Awal & 15.831 .300 & 14.172 .100 & 71.007 .750 & 51.223 .500 & 65.959 .700 \\
\hline $\begin{array}{l}\text { Laba stlh } \\
\text { perlakuan }\end{array}$ & 37.525 .800 & 36.652 .600 & 93.989 .625 & 72.421 .875 & 81.742 .100 \\
\hline Persentase & $57,81 \%$ & $61,33 \%$ & $24,45 \%$ & $29,27 \%$ & $19,31 \%$ \\
\hline
\end{tabular}

Sumber : Data Olahan, Tahun 2020

Berdasarkan table diatas,dapat dideskripsikan bahwa perlakuan akutansi penjualan produk sampingan mengurangi harga pokok penjualan produk utama dapat meningkatkan total laba.Untuk tahun 2015 dapat meningkatkan laba sebesar 57,81\% dari Rp.15.831.300 menjadi Rp. 37.525.800, tahun 2016 dapat meningkatkan laba sebesar $61,33 \%$ dari Rp. 14.172.100 menjadi Rp.36.652.600, tahun 2017 dapat meningkatkan laba sebesar $24,45 \%$ dari Rp.71.007.750 menjadi Rp.93.989.625, tahun 2018 dapat meningkatkan laba sebesar 29,27\% dari Rp.51.223.500 menjadi Rp. 72.421.875, tahun 2019 dapat meningkatkan laba sebesar $19,31 \%$ dari Rp. 65.959 .700 menjadi Rp.81.742.100.

2) Perlakuan Akutansi Penjualan Produk Sampingan Mengurangi Biaya Total Produksi Produk Utama

Tabel 24

Rekapitulasi Total Laba untuk perlakuan akutansi laba produk sampingan mengurangi biaya total produksi produk utama

\begin{tabular}{|l|l|l|l|l|l|}
\hline \multirow{2}{*}{ Uraian } & Laba (Rp) & \multicolumn{5}{|l|}{} \\
\cline { 2 - 6 } & 2015 & 2016 & 2017 & 2018 & 2019 \\
\hline $\begin{array}{l}\text { Laba } \\
\text { Awal sth }\end{array}$ & 15.831 .300 & 14.172 .100 & $\begin{array}{l}71.007 .7 \\
50\end{array}$ & 51.223 .500 & 65.959 .700 \\
\hline $\begin{array}{l}\text { Laba stlh } \\
\text { perlakuan }\end{array}$ & 22.758 .855 & 19.029 .910 & $\begin{array}{l}73.482 .6 \\
37\end{array}$ & 54.799 .162 & 66.394 .820 \\
\hline Persentase & $30,44 \%$ & $25,53 \%$ & $3,37 \%$ & $6,53 \%$ & $0,66 \%$ \\
\hline
\end{tabular}

Sumber : Data Olahan,Tahun 2020

Berdasarkan tabel diatas, dapat dideskripsikan bahwa perlakuan akutansi laba produk sampingan mengurangi biaya total produksi produk utama dapat meningkatkan total laba. Untuk tahun 2015 dapat meningkatkan laba sebesar 30,44\% dari dari 15.831.300 menjadi Rp.22.758.855, tahun2016 dapat meningkatkan laba sebesar $25,53 \%$ dari Rp. 14.172.100 menjadi Rp.19.029.910., tahun 2017 dapat meningkatkan laba sebesar $3,37 \%$ dari Rp.71.007.750 menjadi Rp.73.482.637, tahun 2018 dapat meningkatkan laba sebesar 6,53\% dari Rp.51.223.500 menjadi Rp. 54.799.162, tahun 2019 dapat meningkatkan laba sebesar 0,66\% dari Rp. 66.394.820 menjadi Rp.81.742.100.

3) Hasil Rekapitulasi Total Laba untuk perlakuan akutansi laba produk sampingan

Berdasarkan metode untuk mengalokasikan biaya bersama kepada produk utama dan produk sampingan yang digunakan adalah metode tanpa harga pokok (non-cost methods) yaitu hasil penjualan produk sampingan diperlakukan sebagai laba lain-lain / laba diluar usaha, hasil penjualan produk sampingan diperlakukan sebagai tambahan terhadap hasil penjualan produk utama. Dengan demikian dalam cara ini laba 
usaha bertambah, hasil produk sampingan diperlakukan mengurangi harga pokok penjualan, hasil penjualan produk sampingan diperlakukan mengurangi total biaya produksi. Maka diperoleh data sebagai berikut:

Tabel 25

Rekapitulasi Total Laba untuk perlakuan akutansi laba produk sampingan mengurangi biaya total produksi produk utama

\begin{tabular}{|c|c|c|c|c|c|}
\hline \multirow[t]{2}{*}{ Uraian } & \multicolumn{5}{|c|}{ Laba ( Rp) } \\
\hline & 2015 & 2016 & 2017 & 2018 & 2019 \\
\hline $\begin{array}{l}\text { Produk } \\
\text { sampingan } \\
\text { diperlakukan } \\
\text { sebagai laba } \\
\text { lain-lain } \\
\end{array}$ & 22.758 .855 & 19.029 .910 & 73.482 .637 & 54.799 .162 & 66.394 .820 \\
\hline $\begin{array}{l}\text { Produk } \\
\text { sampingan } \\
\text { diperlakukan } \\
\text { sebagai } \\
\text { tambahan } \\
\text { terhadap hasil } \\
\text { penjualan } \\
\text { produk utama }\end{array}$ & 22.758 .855 & 19.029 .910 & 73.482 .637 & 54.799 .162 & 66.394 .820 \\
\hline $\begin{array}{l}\text { Produk } \\
\text { sampingan } \\
\text { diperlakukan } \\
\text { mengurangi } \\
\text { hargapokok } \\
\text { penjualan }\end{array}$ & 37.525 .800 & 36.652 .600 & 93.989 .625 & 72.421 .875 & 81.742 .100 \\
\hline $\begin{array}{l}\text { Produk } \\
\text { sampingan } \\
\text { diperlakukan } \\
\text { mengurangi } \\
\text { totalbiaya } \\
\text { produksi } \\
\end{array}$ & 22.758 .855 & 19.029 .910 & 73.482 .637 & 54.799 .162 & 66.394 .820 \\
\hline
\end{tabular}

Sumber : Data Olahan,Tahun 2020

Berdasarkan data diatas dapat disimpulkan bahwa jika produk sampingan diperlakukan sebagai laba lain-lain dan produk sampingan diperlakukan sebagai tambahan terhadap hasil penjualan produk utama maka laba bersih yang diperoleh oleh UMKM Kopi Bubuk Istimewa untuk tahun 2015 sebesar Rp.22.758.855, untuk tahun 2016 sebesar Rp. 19.029.910,untuk tahun 2017 sebesar Rp.73.482.637, untuk tahun 2018 sebesar Rp.54.799.162, untuk tahun 2019 sebesar Rp. 66.394.820. Sedangkan jika produk sampingan diperlakukan mengurangi harga pokok penjualan dan produk sampingan diperlakukan mengurangi total biaya produksi ada perbedaan. Untuk tahun 2015 UMKM Kopi Bubuk Istimewa memperoleh laba sebesar Rp.37.525.800, untuk tahun 2016 sebesar Rp.19.029.910, untuk tahun 2017 sebesar Rp.73.482.637, untuk tahun 2018 sebesar Rp.54.799.162, untuk tahun 2019 sebesar Rp. 81.742.100.

\section{KESIMPULAN}

UKM Kopi Bubuk Istimewa belum melakukan perlakuan akuntansi produk sampingan. Dimana penjualan atau laba dari produk sampingan belum dimasukan ke dalam laporan keuangan. Untuk itu peneliti mendeskripsikan 4 perlakuan akutansi memasukan penjualan atau laba dari produk sampingan kedalam laporan keuangan UKM Kopi Bubuk Istimewa. Ada 4 perlakukan yang dianalisis yaitu 1. Produk sampingan diperlakukan sebagai laba lain-lain dapat meningkatkan total laba, Untuk tahun 2015 dapat meningkatkan laba sebesar 30,44\% dari Rp.15.831.300 menjadi Rp.22.758.855, tahun 2016 dapat meningkatkan laba sebesar 25,53\% dari Rp.14.172.100 menjadi Rp.19.029.910, tahun 2017 dapat meningkatkan laba sebesar $3,37 \%$ dari Rp.71.007.750 menjadi Rp.73.482.637, tahun 2018 dapat meningkatkan laba sebesar 6,53\% dari Rp.51.223.500 menjadi Rp. 54.799.162, tahun 2019 dapat meningkatkan laba sebesar 0,66\% dari Rp.65.959.700 menjadi Rp.66.394.820. 2. Perlakuan akuntansi untuk laba produk sampingan menambah laba penjualan produk utama dapat meningkatkan total laba.Untuk tahun 2015 dapat meningkatkan labase besar $30,44 \%$ dari Rp.15.831.300 menjadi Rp.22.758.855, tahun 2016 dapat meningkatkan laba sebesar $25,53 \%$ dari Rp.14.172.100 menjadi Rp.19.029.910, tahun 2017dapat meningkatkan laba sebesar 3,37\% dari Rp.71.007.750 menjadi Rp. 73.482.637, tahun 2018 dapat meningkatkan laba sebesar 6,53\% dari Rp. 51.223.500 menjadi Rp. 54.799.162, tahun 2019 dapat meningkatkan laba sebesar $0,66 \%$ dari Rp.65.959.700 menjadi Rp. 66.394.820. 3. Perlakuan akutansi penjualan produk sampingan mengurangi harga pokok penjualan produk utama dapat meningkatkan total laba. Untuk tahun 2015 dapat meningkatkan laba sebesar $57,81 \%$, tahun 
2016 dapat meningkatkan laba sebesar $61,33 \%$, tahun 2017 dapat meningkatkan labasebesar 24,45\%, tahun2018 dapat meningkatkan laba sebesar $29,27 \%$,tahun 2019 dapat meningkatkan laba sebesar $19,31 \%$ 4. Perlakuan akutansi laba produk sampingan mengurangi biaya total produksi produk utama dapat meningkatkan total laba.Untuk tahun 2015 dapat meningkatkan laba sebesar 30,44\%,tahun 2016 dapat meningkatkan laba sebesar $25,53 \%$, tahun 2017 dapat meningkatkan laba sebesar $3,37 \%$, tahun 2018 dapat meningkatkan laba sebesar 6,53\%, tahun 2019 dapat meningkatkan laba sebesar $0,66 \%$. 5. Jika produk sampingan diperlakukan sebagai laba lain-lain dan produk sampingan diperlakukan sebagai tambahan terhadap hasil penjualan produk utama maka laba bersih yang diperoleh oleh UMKM Kopi Bubuk Istimewa untuk tahun 2015 sebesar Rp.22.758.855, untuk tahun 2016 sebesar Rp.19.029.910, untuk tahun 2017 sebesar Rp. 73.482.637, untuk tahun 2018 sebesar Rp.54.799.162, untuk tahun 2019 sebesar Rp.66.394.820. Sedangkan jika produk sampingan diperlakukan mengurangi harga pokok penjualan dan produk sampingan diperlakukan mengurangi total biaya produksi ada perbedaan. Untuk tahun 2015 UMKM Kopi Bubuk Istimewa memperoleh laba sebesar Rp.37.525.800, untuk tahun 2016 sebesar Rp.19.029.910, untuk tahun 2017 sebesar Rp.73.482.637, untuk tahun 2018 sebesar Rp.54.799.162, untuk tahun 2019 sebesar Rp. 81.742.100.

\section{SARAN}

Setelah melihat pembahasan dan hasil yang telah peneliti simpulkan, maka saran yang peneliti dapat berikan bagi perusahaan adalah sebagai berikut :

1. UKM Kopi Bubuk Istimewa sebaiknya menggunakan perhitungan harga pokok produksi kajian perlakuan akutansi produk sampingan, karena metode tersebut dalam menentukan biaya lebih tepat dan akurat. Sehingga dalam perhitungan harga pokok produksinya UMKM dapat mengetahui informasi biaya secara menyeluruh.

2. UKM Kopi Bubuk Istimewa belum melakukan pencatatan akutansi terhadap penjualan produk sampingan, seharusnya ada pencatatan yang khusus agar lebih bisa mengetahui variable yang mempengaruhi besar kecilnya laba pada produk sampingan .

\section{DAFTAR PUSTAKA}

[1] V.Tirayoh, E.Bawiling, "Analisis Perhitungan Harga Pokok Dan Perlakuan Akuntansi Atas Produk Sampingan Pada Ud Sinar Sakti" ,J. Ris. Ekon. Manajemen, Bisnis dan Akunt.,2,2,.745-754,2014.

[2] A. Witjaksono, Akuntansi Biaya Edisi Pertama.Yogyakarta : Graha Ilmu,2017.

[3] Mulyadi, Akuntansi Biaya Edisi 4. Yogyakarta : Universitas Gajah Mada, 2015.

[4] Irham. Fahmi, Analisis Kinerja Keuangan. Jakarta : Alfabetha, 2015.

[5] Bustami, Akuntansi Biaya Teori dan Aplikasi. Yogyakarta : Graha Ilmu, 2015.

[6] Wasilah, Akuntansi Biaya Untuk Pemula, Graha Ilmu.Yogyakarta, 2016.

[7] Supriyono, Akuntansi Biaya. Jakarta : Graha Ilmu, 2016.

[8] A.Sawir, Kinerja Keuangan. Jakarta : PT. Gramedia Pustaka Utama, 2015.

[9] Prastowo, Metode Riset untuk Bisnis 
dan Ekonomi. Jakarta: Erlangga, 2015.

[10] R. B. Waroh, T. Runtu, J. Akuntansi, F.Ekonomi, U.Sam, gR.Manado, "perlakuan akuntansi atas produk sampingan pada pt. Royal coconut air madidithe accounting treatmentofby productin royal coconut tairmadidi company Oleh : email :Latar Belakang Setiap perusahaan saling memproduksi produk yang terbaik untuk menarikmina",5,1,.125-135,2017.

[11] K.Teplická,"Comparison of Methods for Pricin gof the Productand its Impacton Economic Efficiency of Enterprise", Procedia Econ. Financ., جم .34, 1, doi : 10.1016/s2212- 5671(15)01613-5.

[12] Dwi Anisa Pranata. Perlakuan Akuntansi Terhadap Main Product dan By Product Serta Pengaruhnya Terhadap Laba Perusahaan (Studi Kasus Pada Pabrik Tahu dan Tempe Padang Tarok). 5,1,130-145, 2018.

[13] Sugiyono, Metode Penelitian Bisnis. Bandung : Penerbit CV.Alfabeta, 2015. 